\title{
Financial Competence on the Board Case
}

\author{
by Peter Leibfried \\ (Switzerland/Germany)
}

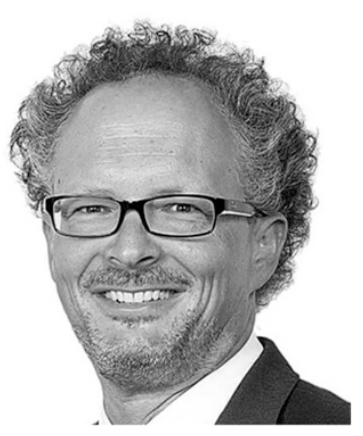

University of St. Gallen

International Center for Corporate Governance

\section{Situation}

Mike Muckelroy is the chairman of the board of a larger Swiss company, with revenues around CHF 600 Mio and about 2000 employees. Being a lawyer himself, he has taken over the position as the chairman about 15 years ago, when being asked to do so by one his clients, the family owning the company. Since almost more than one generation, no one from the family has been actively involved in managing the company. Ownership within the family is somewhat spread, with ten shareholders. No one has the majority, percentages of ownership range from $1 \%$ to $25 \%$. Luckily, so far there have not been any serious conflicts amongst the owners. This is not only due to the wise stewardship of Mike Muckelroy but can probably also be attributed to Allan Parker, who has been CEO of the company for almost 20 years now. Since then, the company has been growing steadily, is producing stable and predictable profits every year and generally seems to be in a perfect shape.

A few months ago, the company has hired a new $\mathrm{CFO}$, as the previous one retired after 25 years of service. Ben Counter is just above 40 and has spent the major part of his professional career in a much larger, yet also family-owned, international company. Shortly after starting to work for your company, he has brought up the issue of changing the company's accounting standards from local Swiss company law (Obligationenrecht) to an international standard such as IFRS (International Financial Reporting Standards).

Mike Muckelroy has been talking to a couple of people about this idea already. However, opinions seem to be quite diverse: 
- The new CFO is heavily in favour of converting to international standards. Unlike many other people within the company's finance and accounting department, he seems to be very energetic, dynamic and motivated.

- CEO Allan Parker is very sceptical of any effort being put into accounting in general. In his eyes, accounting is a legal burden which unfortunately cannot be avoided but does not provide any benefits in terms of sales or innovation. Thus, he would like to keep everything as is.

- The two main shareholders of the family (25\% each) are also quite happy with what they receive and also would like to save cost.

- The external auditor-a small, local firm-is also pretty reserved. However, a sales presentation made by one of the Big4 audit firms about a year ago also suggested that converting to IFRS would a good idea.

- Besides Mike Muckelroy as a lawyer, the board of the company consists of former top management employees of the company and a few family members. No one has professional experience in the finance sector.

What should Mike Muckelroy do? To advise him, please be aware: besides what can be directly taken from the case, what might be the driving factors for the positions taken by the various stakeholders above?

\section{$2 \quad$ What Happened in Reality?}

After a lengthy debate (with the CFO almost leaving again), the company decided to change its accounting system to an international standard. The consequences were quite significant:

- Under the local accounting system, the company apparently had made great use of earning management techniques to hide profits (in good years) and losses (in bad years).

- It became visible that the company's financial situation is much more volatile (and vulnerable) than the shareholders have thought. It turned out that the company can react much better and quicker, if fluctuations in the market are shown in the financial statements.

- The CEO apparently tried to calm the owners by smoothing income, also having a positive effect on top management compensation (as the budget was always reached).

- It also turned out that the two major shareholders had a different view on the company than the rest of the owners. While the larger shareholders wanted to increase long-term company value, the smaller shareholders largely were focussed on dividend distribution. The new accounting also led to fruitful discussions amongst the shareholders about what governance rules to follow amongst them.

- The necessary work to adapt the accounting system caused significant personal overturn in the finance department and also in IT. At the end, almost all former 
accountants had left the company, and a younger, more dynamic and more business-oriented team was in charge. This was to the benefit of the operating management, too. Also, new accounting software was introduced, which produced more reliable and up-to-date numbers.

- Also, the audit firm changed, from the smaller company to a Big4 company. Later on, this was also helpful in international tax issues and when international acquisitions came along. It was, however, significantly more expensive than before.

- In the future, not only the CEO and the inner circle of top management really knew how the company was performing, but there was one version of the truth throughout the broader management and the shareholders.

\section{$3 \quad$ Takeaways}

While accounting at first sight always seems to be about numbers only, in reality, it does heavily involve people and culture. Thus, also general management should be open to the respective issues, and not push it into a technical, sometimes even "nerdy" corner. Very often, discussions about numbers are in reality discussions about underlying business or cultural issues. In order to bring them up, the board needs at least one member (financial expert) who is on a level playing field with the $\mathrm{CFO}$ and the auditor and will not be distracted by (presumably) complicated technical questions.

Open Access This chapter is licensed under the terms of the Creative Commons Attribution 4.0 International License (http://creativecommons.org/licenses/by/4.0/), which permits use, sharing, adaptation, distribution and reproduction in any medium or format, as long as you give appropriate credit to the original author(s) and the source, provide a link to the Creative Commons licence and indicate if changes were made.

The images or other third party material in this chapter are included in the chapter's Creative Commons licence, unless indicated otherwise in a credit line to the material. If material is not included in the chapter's Creative Commons licence and your intended use is not permitted by statutory regulation or exceeds the permitted use, you will need to obtain permission directly from the copyright holder.

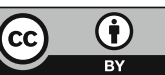

